\title{
Sapwood Cuts and Their Impact on Tree Stability
}

\author{
E. Thomas Smiley, Brian Kane, Wesley R. Autio, and Liza Holmes
}

\begin{abstract}
Sapwood may be lost due to wood decay fungi or mechanical damage. Assessing the impact of sapwood loss on the likelihood of tree failure has not been empirically tested. The purpose of this research was to determine the effect of the loss of sapwood on the flexural stiffness of tree trunks for different species and trunk sizes. Three tree species (Acer rubrum, Liquidambar styraciflua, and Quercus acutissima) were tested at two sites using pull testing techniques. A portion of the stem was mechanically removed and the trees were again pull tested. As the percent reduction in cross-sectional area increased, the percent reduction in stress to deflect trunks decreased linearly, regardless of species. Stress from sapwood loss was compared to an equivalent calculated loss in heartwood with the same cross-sectional area. The calculated loss of heartwood to cause an equivalent magnitude of stress was almost twice as large as cut area of sapwood. Trees were also tested by pulling in opposite directions with respect to sapwood loss. The percentage reduction in stress was greater for trees tested in compression.

Key Words. Acer rubrum; Decay; Likelihood of Impact; Liquidambar styraciflua; Notch Cuts; Quercus acutissima; Sapwood Loss; Strength Loss; Tree Risk Assessment.
\end{abstract}

Tree risk assessment is an area of concern to many arborists. Most risk assessment is currently being conducted using a basic visual assessment of the tree. Advanced assessment techniques have been developed that relate heartwood loss with the percent strength loss or loss in moment of inertia of the stem (Wagener 1963; Smiley \& Fraedrich 1992; Mattheck and Breloer 1994; Kane et al. 2001; Kane and Ryan 2004). The percent strength loss has been used as a surrogate for likelihood of failure, but it does not account for other variables that would affect likelihood of failure, such as the wind-induced bending moment on the stem. Wagener (1963) suggested the maximum allowable loss of one third of the initial strength, which corresponded to a heartwood loss of $70 \%$ (measured by the diameter of decay). This threshold was supported by Smiley and Fraedrich's (1992) measurement of failed and standing trees after Hurricane Hugo. However, when trees are exposed to severe wind ( $>93 \mathrm{~km} / \mathrm{hr}$ ), even trees with no strength loss can fail (Smiley et al. 2011).

There is less research on the effects of the loss of sapwood or wood in the outer stem, which may be lost due to wood decay fungi or mechanical damage. Damage may occur from vehicle collisions, fire, animals (e.g., beavers), or other causes that remove xylem from the outer stem. Luley and Kane (2009) presented a simple theoretical approach to how loss of sapwood would affect a tree's strength, but did not conduct any tests. The parallel axis theorem can be used to show that for a given shape and area of removed wood, the moment of inertia of the stem will be reduced by a greater amount if the wood is removed from the sapwood rather than the heartwood.

Tree winching and breaking studies have been conducted on forest trees for many years (Peltola 2006), but fewer studies have considered open grown deciduous trees (Kane and Clouston 2008). Most of this work involves applying a single point load to the tree until it fails. Alternatively, trees can be loaded in the same way, except that the load is limited to induce trunk strains that remain in the elastic range of the wood. This approach has been used to assess the probability of failure in standing trees (Wessolly 1995; Brudi and van Wassenaer 2001) and the effect of the progressive removal of roots (Smiley 2008). Testing in this way reduces the number of trees needed to demonstrate an effect. The purpose of this research was to empirically determine the effect of the loss of sapwood on the flexural stiffness of tree trunks for different species and trunk sizes.

\section{MATERIALS AND METHODS}

Three tree species [red maple (Acer rubrum), sweetgum (Liquidambar styraciflua), and sawtooth oak (Quercus acutissi$m a)$ ] were tested at two United States sites (Table 1). Smaller diameter trees were tested at the Bartlett Tree Research Laboratories in Charlotte, North Carolina, and larger diameter red maples were tested at Davey Research Farm in Shalersville, Ohio. The soil type on which the trees were growing in NC was a Cecil sandy clay loam, and in Ohio, a Ravenna silt loam.

On all trees, a digital level (Sears Craftsman model 48293, 60 $\mathrm{cm}$ long, accurate to $>0.1$ degrees) was attached vertically to the trunk with the lower end of the level $45 \mathrm{~cm}$ above grade (Smiley 2008) (Figure 1). A polyester rope $12 \mathrm{~mm}$ in diameter (small trees) or a wire rope $6 \mathrm{~mm}$ (large trees) or cable was attached to the trunk at a standard height $(3.6 \mathrm{~m}$ on large trees and $1.5 \mathrm{~m}$ on small trees). Trees were pulled until the level measured an angle of one degree from vertical. A small angle was chosen to ensure that axial strains remained in the elastic range of the wood. A dynamometer (Dillon ED-200+, Fairmont, Minnesota, U.S.) measured the maximum tension in the rope while the tree was pulled. 
Each tree was pulled three times and the mean value of force was used in subsequent calculations and analyses. After the initial series of pulls, a chain saw was used to make a shallow $(0.5-2 \mathrm{~cm})$ cut perpendicular to the long axis of the trunk at $45 \mathrm{~cm}$ above grade on the same side of the tree to which the rope was connected, compressing the cut when the tree was pulled. The tree was then pulled again using the same procedure. A second cut was then made slightly below the first cut to a $0.5-2 \mathrm{~cm}$ greater depth. The tree was pulled again using the same procedure. Typically, there were four cuts in each small tree and six cuts made on each large tree. The chain saw kerf was $7 \mathrm{~mm}(+1 \mathrm{~mm})$. On average, the height per cut was $7.7 \mathrm{~mm}$ on the small trees and $12 \mathrm{~mm}$ on the large trees. The process was repeated until the chainsaw operator felt that the tree may have been unstable. This method allowed for comparatively easy calculations of the area of removed wood.

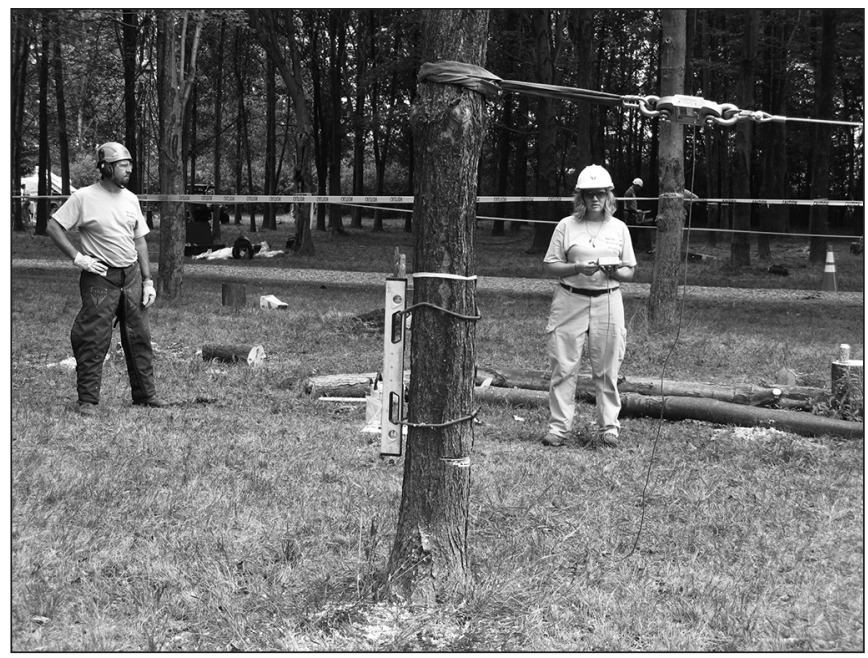

Figure 1. Setup of notch cutting showing three notch cuts, dynamometer, and digital level attached to trunk.

Ten of the small red maples were treated in a similar fashion, except they were pulled both toward and away from the cut to compare the difference in cutting wood on the compression and tension side of the stem. The same pulling and measuring equipment was used in both directions. The level remained attached to the tree in the same location for both directions of pull.

After the final notch cut, the tree was felled with a horizontal cut above the series of notch cuts. The section of the trunk containing the series of notch cuts was then removed from the stump for measurement (Figure 2). Measurements made on each notched section of trunk were: 1) the diameter of the trunk incident to the direction of the applied load, 2) the cross-sectional area of each cut segment, and 3) the total cross-sectional area of the section.

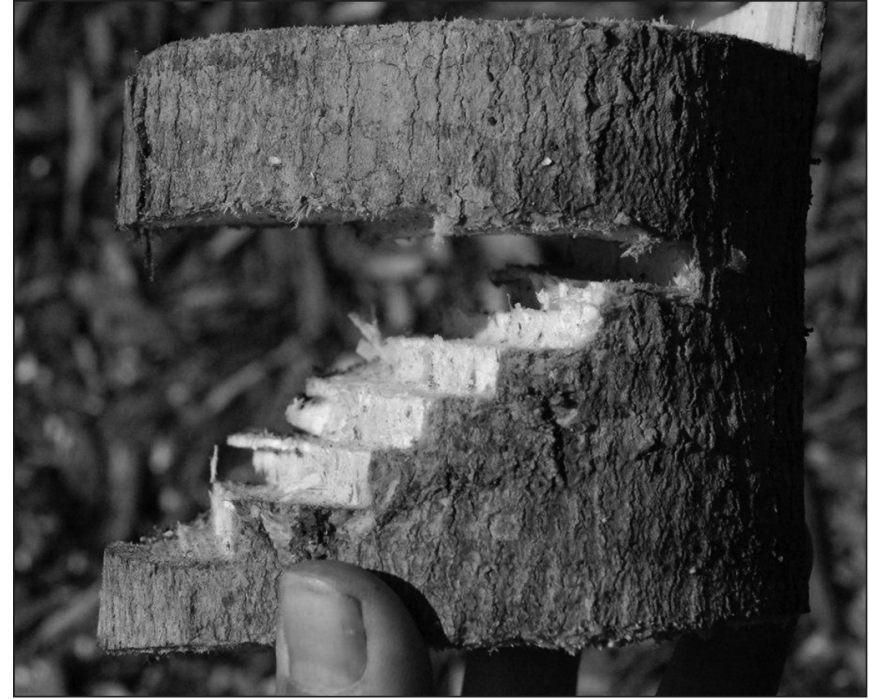

Figure 2. Section of small tree notch cuts used to calculate area of the cuts and total stem cross-sectional area.

To account for different trunk diameters among trees, bending $\left(\sigma_{\mathrm{B}}\right)$ and axial $\left(\sigma_{\mathrm{A}}\right)$ stress were calculated as follows:

[1] $\sigma_{\mathrm{B}}=32 \mathrm{PL} \sin \theta /\left(\pi \mathrm{d}^{3}\right)$

[2] $\quad \sigma_{\mathrm{A}}=\mathrm{P} \cos \theta / \mathrm{A}$

where $\mathrm{P}$ is mean force, $\mathrm{L}$ is the distance between the rope and the bottom of the level, $\mathrm{d}$ is trunk diameter incident to the direction of the applied load, $\sigma$ is the angle made between the rope and the trunk, and A is the measured cross-sectional area of the trunk $45 \mathrm{~cm}$ above the ground. Total stress is the sum of Equation 1 and Equation 2. After trees were cut, stress was re-calculated using the post-cut values of $\mathrm{P}$ in Equations 1 and 2 but assuming an uncut cross section. This was done because it was not possible to account for post-cut changes to the geometry of the cross section accurately enough to calculate the post-cut moment of inertia of the cross section. Approximating the post-cut moment of inertia using simple shapes, such as parabolas, semi-circles, and trapezoids, produced unrealistic results. The area removed by cutting was standardized by dividing the cross-sectional area of each cut by the total cross-sectional area to yield the percent change in area. The post-cut change in stress was standardized by dividing post-cut stress by the pre-cut stress (both based on the uncut cross section) to yield percent change in stress. For the subset of small red maples tested in compression and tension, stress and percent change in stress were calculated the

Table 1. Descriptive information of trees used in the study. Pre-cut means of trunk diameter $(\mathrm{cm}), \mathrm{cross}^{-s e c t i o n a l ~ a r e a ~}\left(\mathrm{~cm}^{2}\right)$, and stress (MPa) were measured $45 \mathrm{~cm}$ aboveground.

\begin{tabular}{|c|c|c|c|c|c|c|}
\hline Species & Location & $\mathrm{N}_{\text {TREES }}$ & $\mathrm{N}_{\text {CUTS }}$ & Diameter $^{2}$ & $\begin{array}{l}\text { Cross-sectional } \\
\text { area }^{z}\end{array}$ & Stress $^{y}$ \\
\hline Red maple & $\mathrm{NC}$ & 15 & 58 & $10.3(0.81)$ & $89.0(6.78)$ & $15.0 \mathrm{a}$ \\
\hline Red maple & $\mathrm{OH}$ & 10 & 49 & $25.7(1.11)$ & $486(40.2)$ & $29.6 b$ \\
\hline Sawtooth oak & $\mathrm{NC}$ & 10 & 42 & $16.2(1.01)$ & $174(17.7)$ & $14.3 \mathrm{a}$ \\
\hline
\end{tabular}

${ }^{\mathrm{z}}$ Means are followed by standard deviation in parentheses.

${ }^{y}$ Means followed by the same letter are not significantly different $(P>0.001)$ by Tukey's HSD test. 
same way, except two post-cut values (putting the cut in tension and in compression) were calculated for each cut depth.

To compare the effect of sapwood loss versus heartwood loss, the concentric area of heartwood that would need to be removed to cause a magnitude of stress equivalent to that induced by cutting sapwood was calculated. For concentric loss of heartwood, stress was calculated:

$$
\text { [3] } \sigma=32 \mathrm{PL} \sin \theta /\left[\pi\left(\mathrm{d}_{\mathrm{o}}^{3}-\mathrm{d}_{\mathrm{i}}^{3}\right)\right]+4 \mathrm{P} \cos \theta /\left[\pi\left(\mathrm{d}_{\mathrm{o}}^{2}-\mathrm{d}_{\mathrm{i}}^{2}\right)\right]
$$

where the first and second terms in the right-hand side of the equation are bending and axial stress, respectively; $\mathrm{P}$ is the post-cut load for each depth of cut; $d_{o}$ is trunk diameter; $d_{i}$ is diameter of the concentric loss of heartwood; and $\mathrm{L}$ and $\theta$ are described in Equations 1 and 2. Equation 3 was set equal to the pre-cut magnitude of stress and solved for $\mathrm{d}_{i}$, which was subsequently converted into the area of concentric loss of heartwood.

Data were subjected to analysis of covariance using PROC MIXED of the Statistical Analysis Systems (SAS) Software (SAS Institute, Cary, North Carolina, U.S.). Differences among species with respect to 1) the percent change in stress and 2) the percent loss of concentric heartwood were assessed with percent reduction in cross-sectional area as a covariate. Large red maples tested in Ohio were considered a separate species in the analysis and the effect of site was not considered. Regression analyses using PROC REG of SAS were used to fit the best linear relationships between reductions in crosssectional area and the dependent variables (percent change in stress and area of concentric loss of heartwood). Second- and third-order polynomials were assessed but did not contribute significantly more understanding of the relationships than did linear models alone. The experimental design confounded the effect of the tree with that of the area of removed wood, so tree-to-tree variation was lumped with random error, a more conservative approach. Mean separation among species was by Tukey's HSD $(P=0.05)$. For the subset of small red maples, similar analyses were conducted to assess the difference between pulling under tension or compression and potential interacting effects with percent reduction in crosssectional area. A paired t-test was used to determine whether pre-cut stress differed between the two directions of pull.

\section{RESULTS}

Prior to cutting, the stress required to deflect the trunks one degree was greater for large red maples than for small sweetgums (Table 1). As the percent reduction in crosssectional area increased, the percent reduction in stress to deflect trunks one degree decreased linearly, regardless of species (Figure 3). As the percent reduction in cross-sectional area increased, the calculated percent loss in concentric heartwood increased linearly, regardless of species (Figure 4). The mean calculated percent loss in concentric heartwood for all species and cuts was $70 \%$, while the mean loss in area due to cutting was only $39 \%$.

The mean pre-cut stress required to deflect the trunks one degree was similar when the subset of small red maples was pulled in tension (17.2 $\mathrm{MPa}$ ) and in compression $(17.2 \mathrm{MPa})(\mathrm{p}=0.7808)$. After cutting, the mean percent reduction in stress to deflect trunks one degree was greater when trees were pulled on the side of the tree with the cut $(62 \%)$ than on the side opposite the cut $(54 \%)(\mathrm{p}=0.0003)$. As the percent reduction in crosssectional area increased, the percent reduction in stress to deflect trunks one degree decreased linearly, regardless of the direction in which the trees were pulled (Figure 5).

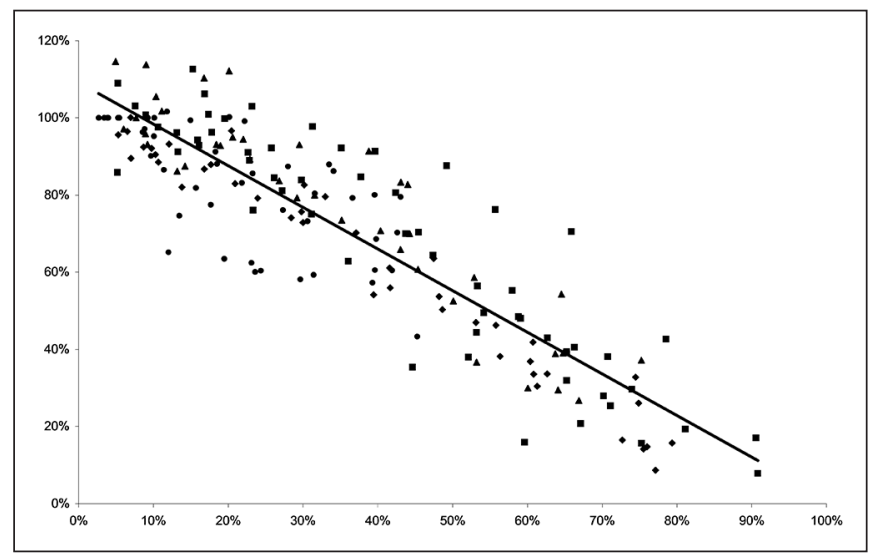

Figure 3. Scatterplot and best-fit line for the relationship between the percent reduction in area $(\triangle A$, abscissa, $x$-axis) and the percent change in stress due to cutting ( $\Delta \sigma$, ordinate, $y$-axis). The latter ratio was calculated assuming an uncut cross section. The scatter plot includes data from small red maple ( $\square$ ), large red maple $(\bullet)$, sweetgum $(\triangle)$, and sawtooth oak $(\diamond)$. The relationship $\left(\Delta \sigma=1.10-1.08{ }^{*} \Delta A\right)$ was significant $(P<0.001)$, robust $\left(r^{2}=0.84\right)$ and similar for all species $(p=0.258)$.

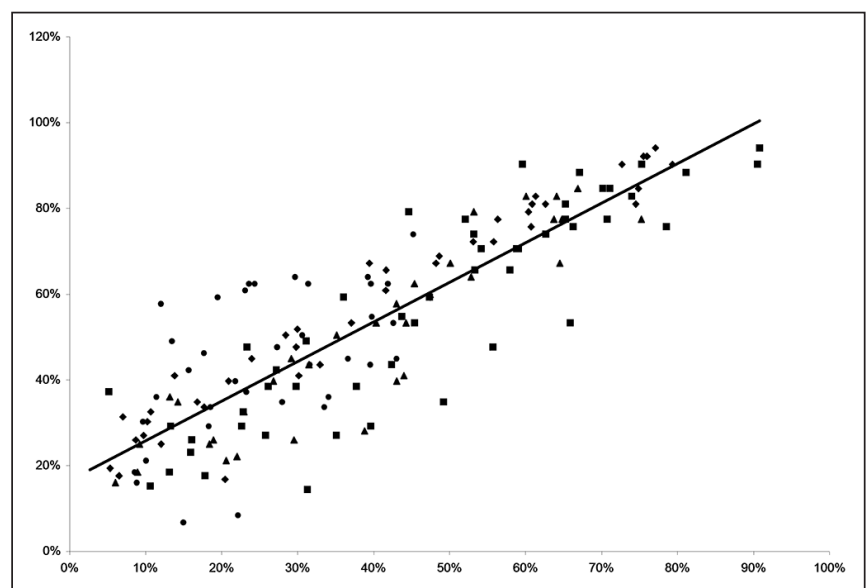

Figure 4. Scatterplot and best-fit line for the relationship between the percent reduction in area ( $\triangle A$, abscissa, $x$-axis) and the percent loss in concentric heartwood to cause an equivalent magnitude of stress to that induced by cutting ( $\triangle \sigma \mathrm{C}$, ordinate, $y$-axis). The scatter plot includes data from small red maple $(\square)$, large red maple $(\bullet)$, sweetgum $(\bullet)$, and sawtooth oak $(\diamond)$. The relationship $\left(\Delta \sigma_{c}=0.17+0.92{ }^{*} \Delta A\right)$ was significant $(P<0.001)$, robust $\left(r^{2}=\right.$ $0.76)$, and similar for all species $(p=0.740)$. 


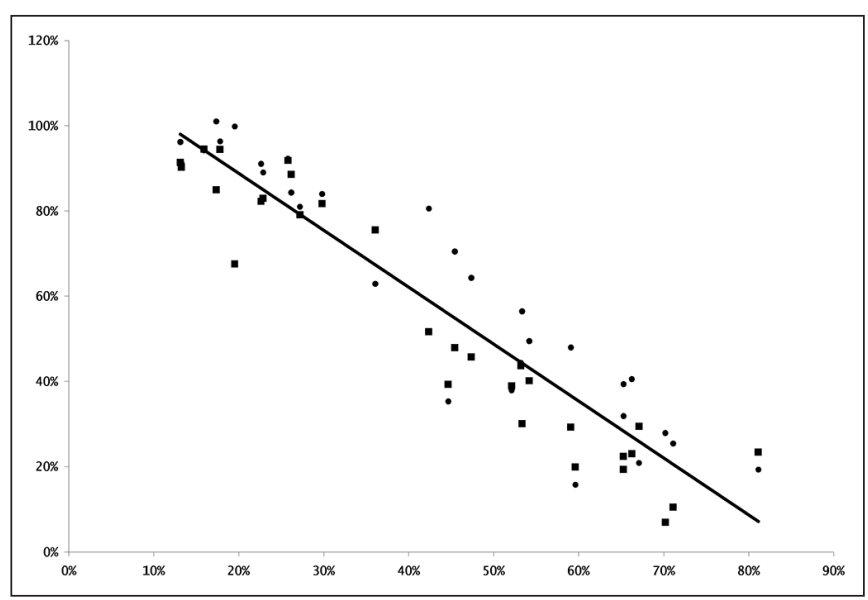

Figure 5. Scatterplot and best-fit line for the relationship between the percent reduction in area $(\triangle A$, abscissa, $x$-axis) and the percent change in stress due to cutting $(\Delta \sigma$, ordinate, $y$-axis). The latter ratio was calculated assuming an uncut cross section. The scatterplot includes data from small red maples measured in tension ( $\square)$ and compression $(\bullet)$. The relationship $(\Delta \sigma=1.16-1.34$ $\left.{ }^{*} \Delta A\right)$ was significant $(P<0.001)$, robust $\left(r^{2}=0.94\right)$, and similar for both directions of measurement $(p=0.727)$.

\section{DISCUSSION}

Greater stress was required to deflect trunks of large red maples because of the smaller proportion of juvenile wood than for the smaller, younger trees. Juvenile wood is known to be less stiff than mature wood for many hardwood species (Williams and Megraw 1994; Zobel and Sprague 1998). Stiffness of juvenile wood is also known to be quite variable and the change from juvenile to mature wood is not abrupt and can vary among species. This may have explained why the pre-cut stress of small red maples and sawtooth oaks was similar, even though inherent stiffness of the wood of sawtooth oak (Zhou et al. 1999) is greater than that of red maple (Kretschmann 2010).

In addition to the lack of accounting for the presence of juvenile wood in stems, two other experimental limitations should be noted. First, assumptions made to calculate stress-for example, that the cross section was circular and that bark thickness was similar across all species-may have introduced error. Although bark thickness was not measured, cross sections visually appeared circular for all species. Second, cutting into trunks would release axial growth stress, which is tensile near the bark and compressive at the pith (the change from tensile to compressive stress occurs at approximately one-third the distance from the bark to the pith) (Wilson and Archer 1977). The magnitude of axial growth stress measured in some genera [Eucalyptus, for example (Archer 1986)] can exceed the pre-cut stress calculated for small trees in the current study. Axial growth stress is inversely proportional to the radius of the trunk (Wilson and Archer 1977).

Experimental limitations appear not to have undermined the results, however, because the reduction in post-cut stress as more area was removed was consistent for all species. The robust relationship lends some confidence that despite presumed differences in wood properties, geometric considerations are more influential. This was expected because the moment of inertia of the uncut trunk (assuming it is circular) is a function of the fourth power of diameter. This reasoning, however, does not explain why the relationship was similar between small and large red maples, given the disparity in trunk diameter. The similarity should be interpreted cautiously because large red maples were not subjected to the same loss of area as small red maples.

The effect of geometry was further illustrated by the finding that the calculated loss of concentric heartwood to cause an equivalent magnitude of stress was almost twice as large as cut area of sapwood. However, it may not be safe to assume that the magnitude of this disparity would apply to trees with trunk decay. Previous work has shown that wood produced in response to wounds can be tougher than normal wood (Kane and Ryan 2003). Cutting the tree and immediately testing it does not allow for this response, nor does it account for an effect on trunk strength due to the axial extent of decay. Both of these effects would likely occur over time to a trunk that was mechanically wounded.

Results should be applied cautiously in practice because trees were only tested in the range of elastic axial strains. Assuming a non-defective stem, failure typically occurs when axial strains are plastic, and non-linear. Future work should investigate the ability to predict failure by measuring elastic axial strains.

It was unclear why the mean pre-cut stress for the subset of small red maples was similar regardless of the direction of pull while the mean post-cut percent reduction in stress was greater for trees tested in compression. Although wood is stronger in tension than compression, when the tree was winched, the neutral axis of the trunk would shift to put proportionally smaller and larger cross-sectional areas of wood in tension and compression, respectively. Experimental limitations (juvenile wood and assumptions used to calculate stress) may have confounded the analysis.

\section{CONCLUSION}

When assessing the likelihood of tree failure, loss of sapwood needs to be carefully considered. On a cross-sectional area basis, sapwood loss can change stress nearly twice as much as an equal amount of heartwood loss. The stress related to loss of sapwood appears largely independent of tree species but is highly dependent on the amount of wood that is missing from a stem. Loss of $10 \%$ of the cross-sectional area of a stem will reduce the strength of the stem a very small amount $(<2 \%)$; however, a loss of a third of the cross-sectional area will reduce strength by a significant amount, about $25 \%$.

The likelihood of a failed tree impacting a target is an important factor in tree risk assessment and often hard to determine. All other factors being equal, trees with sapwood loss or decay on the side of the trunk toward a target may be at a greater likelihood of impacting the target.

Information in this study should be used with caution due to the variability in the data and the difficulty in calculating the amount of cross-sectional area that has been lost on trees in the field. It should also be noted that trees increase in strength over time if they are healthy and produce wood in response to wounding and in response to compression and tension in the cambium. 
Acknowledgments. We would like to thank Robert Bartlett Jr. and the F.A. Bartlett Tree Expert Co. for their support of this research project, and Bruce R. Fraedrich, Ph.D., Director of Research. For assistance with field research: Tyler Wright, Fred Fisher, Chris Bechtel, and Elden Lebrun, F.A. Bartlett Tree Expert Co.; Mark Hoenigman, Busy Bee Services; Mark Noark, Davey Tree Expert Co.; Dr. Jason Grabosky, Irene Donne, Josh Caplin, and Greg Dahle, Rutgers University; Alan Siewert, State of Ohio; and Luana Vargas, International Society of Arboriculture.

This project was in part conducted at the Biomechanics Week, Shalersville, $\mathrm{OH}$. We thank the organizers of that event for hosting this and other research projects, Ward Peterson Davey Tree Expert Co., John Goodfellow, BioCompliance Consulting, and Andrew Koeser, International Society of Arboriculture.

\section{LITERATURE CITED}

Archer, R.R. 1986. Growth Stresses and Strains in Trees. Spring-Verlag NY, New York, U.S. 240 pp.

Brudi, E., and P. van Wassenaer. 2001. Trees and statics: Nondestructive failure analysis. In: E.T. Smiley and K.D. Coder (Eds.). Tree Structure and Mechanics Conference Proceedings: How Trees Stand Up and Fall Down. October 2001, Savannah, GA. International Society of Arboriculture, Champaign, IL. pp. 53-70.

Kane, B.C.P., and H.D.P. Ryan. 2003. Examining formulas that assess strength loss due to decay in trees: Woundwood toughness improvement in red maple (Acer rubrum). Journal of Arboriculture 29(4):208-215.

Kane, B.C.P., and H.D.P. Ryan. 2004. The accuracy of formulas used to assess strength loss due to decay in trees. Journal of Arboriculture 30:347-356

Kane, B., D. Ryan, and D.V. Bloniarz. 2001. Comparing formulae that assess strength loss due to decay in trees. Journal of Arboriculture 27(2):78-87.

Kane, B., and P. Clouston. 2008. Tree pulling tests of large shade trees in the genus Acer. Arboriculture \& Urban Forestry 34:101-109.

Kretschmann, D.E. 2010. Mechanical Properties of Wood. Chapter 5 in Wood Handbook, Wood as an Engineering Material. General Technical Report FPL-GTR-190. Madison, WI: U.S. Department of Agriculture, Forest Service, Forest Products Laboratory.

Luley, C.J., and B. Kane. 2009. Sap rot: It will let you down. Arborist News 18(1):22-27.

Mattheck, C., and H. Breloer. 1994. The Body Language of Trees. The Stationary Office, Norwich, UK. 239 pp.
Peltola, H.M. 2006. Mechanical stability of trees under static loads. American Journal of Botany 93:1501-1511.

Smiley, E.T. 2008. Root pruning and stability of young willow oak. Arboriculture and Urban Forestry 34:123-128.

Smiley, E.T., and B.R. Fraedrich. 1992. Determining strength loss from decay. Journal of Arboriculture 18(4):201-204.

Smiley, E.T., N. Matheny, and S. Lilly. 2011. Best Management Practices: Tree Risk Assessment. ISA Press, Champaign, Illinois, U.S. 81 pp.

Wagener, W.W. 1963. Judging Hazards from Native Trees in California Recreational Areas: A Guide for Professional Foresters. USFS Research Paper PSW-P1, 29 pp.

Wessolly, L. 1995. Fracture diagnosis of trees-Part 1: Statics-Integrated Methods-measurement with tension test. Stadt und Grün 6:416-422.

Williams, C.G., and R.A. Megraw. 1994. Juvenile-mature relationships for wood density in Pinus taeda. Canadian Journal of Forest Research 24:714-722.

Wilson, B.F., and R.R. Archer. 1977. Reaction wood: Induction and mechanical action. Annual Review of Plant Physiology 28:23-43.

Zhou, Y., M. Fushitani, T. Kubo, M. Ozawa. 1999. Bending creep behavior of wood under cyclic moisture changes. Journal of Wood Science 45:113-119.

Zobel, B.J., and J. R. Sprague. 1998 . Juvenile wood in forest trees. Berlin; New York: Springer.

\section{E. Thomas Smiley (corresponding author) \\ Bartlett Tree Research Lab \\ 13768 Hamilton $R d$. \\ Charlotte, North Carolina 28278, U.S.}

\section{Brian Kane}

University of Massachusetts

Amherst, Massachusetts, U.S.

Wesley R. Autio

University of Massachusetts - Stockbridge School of Agriculture Amherst, Massachusetts, U.S.

Liza Holmes

Bartlett Tree Research Lab

13768 Hamilton Rd.

Charlotte, North Carolina 28278, U.S. 
Résumé. Du bois d'aubier peut être perdue en raison des champignons de carie ou des dommages mécaniques. L'évaluation de l'impact de la perte en bois d'aubier sur le risque de bris n'a pas été testé empiriquement. Le but de cette recherche était de déterminer l'effet de la perte en bois d'aubier sur la résistance à la flexibilité du tronc de différentes espèces d'arbres de grosseurs variables. Trois espèces d'arbres (Acer rubrum, Liquidambar styraciflua et Quercus acutissima) ont été évaluées sur deux sites au moyen de tests de traction. Une portion de la tige a été mécaniquement enlevée et les arbres ont à nouveau fait l'objet de tests de traction. Avec le pourcentage de diminution de la section transversale qui s'accroissait, le pourcentage de diminution en stress pour faire plier les troncs s'accroissait de manière linéaire, indépendamment de l'espèce. Le stress associé à la perte en bois d'aubier a été comparé à des données équivalentes de pertes en bois de cœur calculées avec la même section transversale. La perte calculée en bois de cœur nécessaire pour causer une magnitude équivalente de stress était en gros deux fois supérieure à celles de grosses coupes dans le bois d'aubier. Les arbres ont aussi été testés en tirant ces derniers dans la direction opposée par rapport la perte en bois d'aubier. Le pourcentage de diminution en stress était plus grand pour les arbres testés en compression.

Zusammenfassung. Splintholz kann durch Fäule oder mechanische Schäden zerstört werden. Die Überprüfung des Einflusses von Splintholzverlusten auf die Wahrscheinlichkeit des Baumversagens wurde noch nicht empirisch getestet. Die Absicht dieser Studie lag darin, den Effekt von Splintholzverlusten auf die flexurale Steifheit des Stammes in verschiedenen Baumarten und Stammgrößen zu bestimmen. Drei Baumarten (Acer rubrum, Liquidambar styraciflua, und Quercus acutissima) wurden an zwei Standorten mittels Zugprobe getestet. Ein Teil des Stammes wurde mechanisch entfernt und die Bäume wurden erneut gezogen. Als der prozentuale Anteil des Stammquerschnittverlustes zunahm, fiel der prozentuale Anteil an Stressablenkung unabhängig von der Baumart. Stress durch Splintholzverlust wurde verglichen mit einem äquivalenten kalkulierten Verlust an Kernholz im gleichen Stammquerschnittbereich. Der kalkulierte Verlust von Kernholz, um eine äquivalente Magnitude an Stress zu erhalten, war zweimal so hoch wie bei Splintholz. Die Bäume wurden ebenfalls getestet durch Zugproben in die entgegen gesetzte Richtung im Hinblick auf Splintholzverluste. Die prozentuale Stressreduzierung war bei den unter Spannung getesteten Bäumen größer.

Resumen. La albura puede perderse debido a descomposición por hongos o daños mecánicos. La evaluación del impacto de la pérdida de la albura en la probabilidad de falla del árbol no ha sido probada empíricamente. El propósito de esta investigación fue determinar el efecto de la pérdida de albura del tronco de árboles para diferentes especies y tamaños de tronco. Fueron probadas tres especies de árboles (Acer rubrum, Liquidambar styraciflua, y Quercus acutissima) en dos sitios usando técnicas de tirón. Se removió mecánicamente una porción del tronco y los árboles fueron probados nuevamente. A medida que el porcentaje de reducción en la sección trasversal es incrementado, el porciento de reducción en el estrés para deflactar los troncos disminuyó linealmente, sin importar la especie. El estrés de la albura perdida fue comparado a una pérdida equivalente en duramen con la misma área seccional. La pérdida calculada de duramen para causar una magnitud equivalente de estrés fue casi el doble de una gran área de albura. Los árboles también fueron probados tirando en direcciones opuestas con respecto a las pérdidas de albura. El porcentaje de reducción en estrés fue mayor para los árboles probados en compresión. 